\title{
Cellular Development of Skeletal Muscle during Early Periods of Nutritional Restriction and Subsequent Rehabilitation
}

\author{
STEPHEN R. GLORE AND DONALD K. LAYMAN ${ }^{(36)}$
}

Department of Foods and Nutrition, Division of Nutritional Sciences, University of Illinois, Urbana, Illinois, USA

\section{Summary}

This study was designed to examine the effects of early periods of nutritional restrictions on the cellular growth potential of skeletal muscle. Skeletal muscle growth and cell development of male Sprague-Dawley rats were examined at 25 and 100 days of age in controls (c) and three treatment groups. Each of the three treatments consisted of a $50 \%$ restriction of food intake for 21 days through gestation (GR), lactation (LR), and an early postweanling period (PWR, 25-46 days of age). At the conclusion of the restrictions, body weights of the GR, LR, and PWR groups were 85,42 , and $59 \%$ of the weights of their respective age controls. Rehabilitation to 100 days of age enabled the GR, LR, and PWR groups to achieve, respectively, 93,86 , and $93 \%$ of the control group body weight. At 25 and 100 days of age, muscle weights, muscle fiber number, mean fiber diameter, DNA content, and protein content were determined in the soleus and extensor digitorum longus (EDL) muscles. Soleus and EDL muscle weights, DNA contents, and protein contents from the GR and LR groups were significantly less than $C$ group values at 25 days, and the LR group values were significantly less than those from the GR group. When expressed as \% of control values at 100 days, muscle weights and DNA contents were respectively: GR soleus $91 \%$, 92\%; GR EDL 87\%, 89\%; LR soleus 84\%; 86\%; LR EDL 89\%, 80\%; PWR soleus 87\%, 83\%; and PWR EDL 94\%, 91\%. Soleus and EDL muscle fiber numbers were unchanged by the gestational, lactational, and postweanling restrictions at both 25 and 100 days; however, an age-related decrease in fiber number occurred in both muscles for all groups. Reduction in muscle weights resulted from changes in muscle fiber size rather than fiber number. The ability of muscles to recover from a nutritional restriction appears to directly relate to the ability to achieve a normal complement of muscle nuclei (DNA).

Abbreviations

C, control

EDL, extensor digitorum longus

GR, gestation-restricted

LR, lactation-restricted

PWR, postweaning-restricted

The present study was designed to examine the effects of food restriction during gestational, lactational, or postweanling periods on cellular development in skeletal muscle. Early contributions to understanding cellular growth were made by Enesco and Leblond (5) and Winick and Noble (30). These investigators used total DNA to estimate cell number and the ratio of protein/DNA to estimate cell size. Because the amount of DNA per rat diploid nucleus is constant at $6.2 \mathrm{pg}(17)$, cell number is equal to the number of nuclei in tissues consisting of mononucleated cells; however, this approach does not accurately estimate the number of cells in skeletal muscle because muscle cells or muscle fibers are multinucleated (29).
Dietary restrictions that occur shortly after birth reduce body growth and proliferation of muscle nuclei $(16,31)$, but the effects on skeletal muscle fiber number remain equivocal $(1,2,8,9,10$, 13, 16, 18, 24, 26). Rowe (24) and Strickland et al. (26) reported that early food restriction on mice and pigs, respectively, did not alter fiber number. Hegarty and Kim (10) and Layman et al. (13) found a decrease in fiber number in hamsters and rats after total starvation, and Montgomery (18) reported a lower number of muscle fibers in infants who died from protein-energy malnutrition versus normal infants who died in accidents. Recovery of human infants from undernutrition has been reported to involve both hyperplasia and hypertrophy (22), but this finding was based solely on biochemical data and not on direct measurement of muscle fiber number and size. The accumulation of muscle DNA represents a biochemical aspect of growth but does not directly reflect changes in the cellular unit of skeletal muscle. The present study examines changes in both nuclear number (DNA) and muscle fiber number during normal growth and chronic nutritional restriction and after subsequent rehabilitation to determine their relative influences on skeletal muscle growth.

\section{MATERIALS AND METHODS}

Virgin female Sprague-Dawley rats weighing $238 \pm 12 \mathrm{~g}$ were obtained from Harlan Industries (Indianapolis, IN). Each animal was individually housed in a wire-bottomed cage and maintained in a facility with controlled temperature $\left(22-23^{\circ} \mathrm{C}\right)$ and a $12-\mathrm{h}$ light-dark cycle. All rats received tap water ad libitum. The female rats were fed Purina Lab Chow during an initial 4-day acclimation period. The standard purified diet was introduced on the fifth day. This diet contained $20 \%$ casein (32), $0.2 \%$ DL-methionine, $31.15 \%$ glucose, $31.15 \%$ cornstarch, $10 \%$ corn oil, $1 \%$ vitamin mix (33), $3.5 \%$ mineral mix (34), and 3\% cellulose. Mating commenced on the eighth day, and the presence of sperm in a vaginal wash was used to indicate pregnancy. Pups were weighed within a 12-h period after parturition, and on the second day litters were adjusted to contain six pups. Female pups were kept when needed to maintain the litter size at six, but only male pups were used for this study. Food intakes of the ad libitum-fed $\mathrm{C}$ dams were measured daily throughout gestation and lactation. The GR pups were derived from dams which received the restricted diet at the level of $50 \%$ of the intake of the $\mathrm{C}$ group throughout gestation and the standard diet ad libitum during lactation. The restricted diet contained twice the concentrations of vitamins and minerals present in the standard diet; thus, rats consuming half the intake of the $\mathrm{C}$ group were deficient in protein and energy but received adequate vitamins and minerals. The LR pups were derived from dams fed the standard diet ad libitum during gestation and the restricted diet at the 50\% level during lactation. Male pups were weaned at 21 days of age and housed individually in stainless-steel cages. Male pups from the C, GR, and LR groups were sacrificed at 25 days of age. At 25 days of age, one-half of the pups remaining in the control group were assigned to a PWR group, which was fed the restricted diet at the $50 \%$ level for 21 days. At 46 days of 
age, the PWR pups were returned to ad libitum feeding on the standard diet. Male rats from the C, GR, LR, and PWR groups were killed at 100 days of age.

Pups were killed with chloroform; the two hindlimb muscles, the soleus and EDL, were removed and weighed. All visible connective tissue was removed from the soleus and EDL muscles, and samples of $20-50 \mathrm{mg}$ were weighed and frozen in $8 \mathrm{ml}$ of distilled water for determination of DNA, RNA, and protein. After thawing, the samples were homogenized for $20 \mathrm{sec}$ with a Brinkman PCU-5 Polytron at a power setting of 4.5. Homogenates were assayed in duplicate for protein, DNA, and RNA using the Munro and Fleck (19) modification of the method of Schmidt and Thannhauser (25). DNA determinations were made using the indole method as described by Ceriotti (3). Protein was determined by the method of Lowry et al. (14). The contralateral soleus and EDL muscles were dissected after the onset of rigor mortis and stored for at least 10 days in $15 \mathrm{ml}$ of $10 \%$ formalin with $0.1 \mathrm{M}$ phosphate buffer at $\mathrm{pH}$ 7.4. Muscle fiber number and diameter were determined using the method of Thompson et al. (27). This method utilizes a Coulter Counter and Channelizer (Hialeah, FL) to simultaneously determine mean fiber diameter and fiber number. The soleus and EDL muscles were used because they represent slow-twitch, red and fast-twitch, white muscle types and also because the fibers have been shown to extend from origin to insertion (12); thus, all fibers are represented in every cross-section. Statistical analyses were performed using analysis of variance and $t$ tests (11). Because the dietary treatments for the C, GR, and LR groups were applied directly to the dams, each litter represented one experimental unit. The numbers of litters used for the C, GR, and LR groups were, respectively, 7, 6, and 4, whereas the numbers of sampling units (pups) per group ranged from 9-16. The experimental units for the PWR group were the individual male rats because this dietary treatment was administered directly to them.

\section{RESULTS AND DISCUSSION}

Three dietary restrictions were used to examine the relative influence of $50 \%$ food restrictions during different periods of skeletal muscle development and to differentiate the importance of muscle fiber number, fiber size, and nuclear number in controlling or limiting muscle growth. At the conclusion of each of the restrictions, the body weights for the GR, LR, and PWR groups were 85,42 , and $59 \%$ of the weights of their respective age controls (Table 1). Although each restriction retarded growth, the body weight of only the LR group remained statistically smaller than an age-matched $C$ group after rehabilitation until 100 days of age. Previously, other investigators $(6,30)$ have reported that lactational restrictions produce irreversible growth stunting. Body weights of the present GR and PWR groups remained 8\% less than the age control at 100 days, but their patterns of growth differed. The GR group demonstrated catch-up growth until 60

Table 1. Body weights ${ }^{1,2}$

\begin{tabular}{rrrrr}
\hline \multirow{2}{*}{$\begin{array}{c}\text { Age } \\
\text { (day) }\end{array}$} & \multicolumn{4}{c}{ Dietary treatments $^{3}$} \\
\cline { 2 - 5 } & $\mathrm{C}$ & GR & LR & PWR \\
\hline 1 & $6.5 \pm 0.2^{\mathrm{a}}$ & $5.5 \pm 0.2^{\mathrm{b}}$ & $6.0 \pm 0.1^{\mathrm{ab}}$ \\
21 & $69 \pm 1.5^{\mathrm{a}}$ & $62 \pm 1.6^{\mathrm{b}}$ & $29 \pm 1.7^{\mathrm{c}}$ & $70 \pm 1.5^{\mathrm{a}}$ \\
25 & $91 \pm 2.2^{\mathrm{a}}$ & $82 \pm 1.8^{\mathrm{b}}$ & $50 \pm 2.5^{\mathrm{c}}$ & $91 \pm 1.5^{\mathrm{a}}$ \\
46 & $256 \pm 5.7^{\mathrm{a}}$ & $246 \pm 8.2^{\mathrm{a}}$ & $201 \pm 12.7^{\mathrm{b}}$ & $152 \pm 1.7^{\mathrm{c}}$ \\
60 & $352 \pm 7.0^{\mathrm{a}}$ & $342 \pm 15.1^{\mathrm{a}}$ & $292 \pm 19.5^{\mathrm{b}}$ & $293 \pm 6.9^{\mathrm{b}}$ \\
74 & $409 \pm 11.0^{\mathrm{a}}$ & $391 \pm 20.6^{\mathrm{ab}}$ & $350 \pm 23.5^{\mathrm{b}}$ & $361 \pm 9.8^{\mathrm{b}}$ \\
88 & $463 \pm 12.9^{\mathrm{a}}$ & $428 \pm 26.1^{\mathrm{ab}}$ & $396 \pm 28.0^{\mathrm{b}}$ & $411 \pm 11.9^{\mathrm{b}}$ \\
100 & $482 \pm 12.4^{\mathrm{a}}$ & $449 \pm 28.2^{\mathrm{ab}}$ & $416 \pm 29.0^{\mathrm{b}}$ & $447 \pm 12.5^{\mathrm{ab}}$ \\
\hline
\end{tabular}

${ }^{1}$ Mean (g) \pm S.E.M. See "Materials and Methods" for description of treatments and group sizes.

${ }^{2}$ Treatment means not sharing a common superscript are statistically different $(P<0.05)$.

${ }^{3} \mathrm{C}$, control; GR, gestation-restriction; LR, lactation-restriction; and PWR, postweanling-restriction. days of age; however, the body weight of this group expressed as a \% of the control group weight decreased over the last 40 days of the study. This delayed effect of the gestational restriction agrees with the findings of Chow and Stephan (4). Contrary to the GR group, the PWR group appeared to still be undergoing catch-up growth at 100 days. Winick and Noble (30) reported that a restriction similar to the PWR treatment during the first 3 wk after weaning produced permanent growth retardation, but the results of Widdowson and McCance (28) indicated total recovery from such a dietary restriction.

At 25 days of age, both the red soleus (Table 2) and the white EDL (Table 3) from the GR and LR groups weighed significantly less than the muscles of the $\mathrm{C}$ group. Weights of the soleus and EDL from the LR group, expressed as \% of body weight, were greater than the $\mathrm{C}$ group values; thus, the growth of these muscles during lactational restriction was compromised less than other components of the body. Faust et al. (6) reported that lactational restriction reduced the accumulation of fat. Likewise, in the present study, the LR group had approximately $75 \%$ less adipose tissue in both the inguinal and epididymal fat depots at 25 days (data not shown); thus, skeletal muscle growth had priority over fat deposition during the lactation restriction. The GR group at 25 days did not exhibit any changes in the ratio of muscle weight to body weight.

The soleus and EDL of the GR and LR groups contained significantly less total muscle DNA and protein than did their age controls at 25 days. Protein/DNA ratios for both muscles of the LR group were lower than $C$ group values. The reduced protein/ DNA ratios showed that protein accretion was relatively more affected than DNA accumulation by the lactational restriction. The ratio of RNA/DNA indicates protein synthetic capacity. The elevated RNA/DNA ratios in the muscles of the LR group, and to a lesser extent of the GR group, suggest that these muscles were undergoing catch-up growth as a result of the refeeding.

At 100 days of age, muscle weights of the soleus from the LR and PWR groups and of the EDL from the GR group were significantly less than $C$ group values. But no significant differences exist between the control and treatment groups for the ratio of muscle weight to body weight. Although the LR group had approximately $40 \%$ less total inguinal and epididymal fat compared with the controls (data not shown), the ratio of muscle weight to body weight for the soleus and EDL muscles was not different from the control values. Because skeletal muscle accounts for approximately $40 \%$ of the weight of a $100 \mathrm{~g}$ rat, it is not surprising that muscle mass directly relates to body weight and that extreme differences in body fat (i.e., greater than 40\%) are necessary to significantly alter this relationship in the growing rat.

Biochemical analyses of the soleus and EDL at 100 days showed that total muscle DNA in both muscles from each treatment was lower than control values, and that protein/DNA ratios for all treatments were equal to or slightly greater than the $C$ group ratios. Gordon et al. (7) and Layman et al. (12) have reported that the maximum number of muscle nuclei is attained between $80-$ 100 days of age; thus, reductions in the rate of accumulation of nuclei that occur during the period of nuclear proliferation should result in a permanent deficit unless corrected by an accelerated rate before 100 days of age. A second mechanism for catch-up growth would be to prolong the period of DNA accumulation. In this study the reduction in DNA content was very similar to the reduction of muscle weight for each treatment. When expressed as $\%$ of control values at 100 days, muscle weights and DNA contents, respectively were: GR soleus $91 \%, 92 \%$; GR EDL $87 \%$, $89 \%$; LR soleus $84 \%$, $86 \%$; LR EDL $89 \%$, $80 \%$; PWR soleus $87 \%$, $83 \%$; and PWR EDL $94 \%, 91 \%$. These relationships of DNA to muscle weight support the theories of Munro and Gray (20) and Winick and Nobe (31) that total muscle DNA is a critical factor controlling muscle growth.

The number of muscle fibers and their diameters were determined for the soleus and EDL muscles (Table 4). Fiber number was unaffected by the dietary restrictions as determined at either 25 or 100 days; however, an age-related decrease in the number of fibers occurred in both muscles during all treatments. By averaging 
Table 2. Changes in nucleic acids and protein in the soleus after nutritional restriction and rehabilitation ${ }^{1,2}$

\begin{tabular}{|c|c|c|c|c|c|c|}
\hline \multirow[b]{2}{*}{ Group } & \multicolumn{2}{|c|}{ Muscle Weight } & \multirow[b]{2}{*}{ Total DNA $(\mu \mathrm{g})$} & \multirow[b]{2}{*}{$\begin{array}{l}\text { Total protein } \\
(\mathrm{mg})\end{array}$} & \multirow[b]{2}{*}{$\frac{\text { mg Protein }}{\text { mg DNA }}$} & \multirow[b]{2}{*}{$\frac{\mu \mathrm{g} \mathrm{RNA}}{\mu \mathrm{g} \mathrm{DNA}}$} \\
\hline & $\mathrm{mg}$ & $\begin{array}{c}\% \text { Body wt. } \\
\times 10^{-4}\end{array}$ & & & & \\
\hline \multicolumn{7}{|l|}{ Age, 25 days } \\
\hline $\mathrm{C}$ & $\begin{array}{l}35^{\mathrm{a}} \\
(0.8)\end{array}$ & $\begin{array}{c}3.9^{\mathrm{a}} \\
(0.1)\end{array}$ & $\begin{array}{l}54^{\mathrm{a}} \\
(1.1)\end{array}$ & $\begin{array}{c}4.6^{\mathrm{a}} \\
(0.2)\end{array}$ & $\begin{array}{l}86^{\mathrm{a}} \\
(2.5)\end{array}$ & $\begin{array}{c}2.5^{\mathrm{a}} \\
(0.1)\end{array}$ \\
\hline GR & $\begin{array}{l}32^{\mathrm{b}} \\
(0.9)\end{array}$ & $\begin{array}{r}3.9^{\mathrm{a}} \\
(0.1)\end{array}$ & $\begin{array}{l}45^{\mathrm{b}} \\
(2.0)\end{array}$ & $\begin{array}{c}3.7^{6} \\
(0.2)\end{array}$ & $\begin{array}{l}82^{\mathrm{a}} \\
(2.2)\end{array}$ & $\begin{array}{r}2.6^{\mathrm{a}} \\
(0.1)\end{array}$ \\
\hline LR & $\begin{array}{l}21^{\mathrm{c}} \\
(1.4)\end{array}$ & $\begin{array}{r}4.2^{\mathrm{b}} \\
(0.1)\end{array}$ & $\begin{array}{l}31^{\mathrm{c}} \\
(2.0)\end{array}$ & $\begin{array}{r}2.1^{\circ} \\
(0.2)\end{array}$ & $\begin{array}{l}68^{\mathrm{b}} \\
(1.2)\end{array}$ & $\begin{array}{r}2.9^{\mathrm{b}} \\
(0.1)\end{array}$ \\
\hline \multicolumn{7}{|l|}{ Age, 100 days } \\
\hline $\mathrm{C}$ & $\begin{array}{l}79^{a} \\
(8.3)\end{array}$ & $\begin{array}{r}3.6^{\mathrm{a}} \\
(0.1)\end{array}$ & $\begin{array}{l}131^{\mathrm{a}} \\
(7.6)\end{array}$ & $\begin{array}{l}29^{\mathrm{a}} \\
(1.6)\end{array}$ & $\begin{array}{l}219^{\mathrm{a}} \\
(5.7)\end{array}$ & $\begin{array}{r}3.0^{\mathrm{a}} \\
(0.1)\end{array}$ \\
\hline GR & $\begin{array}{r}163^{\mathrm{ab}} \\
(5.3)\end{array}$ & $\begin{array}{r}3.7^{a} \\
(0.1)\end{array}$ & $\begin{array}{r}121^{\mathrm{ab}} \\
(6.1)\end{array}$ & $\begin{array}{l}27^{\mathrm{a}} \\
(0.8)\end{array}$ & $\begin{array}{l}225^{\mathrm{a}} \\
(9.0)\end{array}$ & $\begin{array}{l}3.1^{\mathrm{a}} \\
(0.1)\end{array}$ \\
\hline LR & $\begin{array}{c}151^{\mathrm{b}} \\
(8.5)\end{array}$ & $\begin{array}{r}3.6^{\mathrm{a}} \\
(0.2)\end{array}$ & $\begin{array}{r}113^{\mathrm{ab}} \\
(9.5)\end{array}$ & $\begin{array}{l}25^{\mathrm{a}} \\
(1.5)\end{array}$ & $\begin{array}{l}226^{a} \\
(11.0)\end{array}$ & $\begin{array}{r}3.2^{\mathrm{a}} \\
(0.2)\end{array}$ \\
\hline PWR & $\begin{array}{l}155^{\mathrm{b}} \\
(5.3)\end{array}$ & $\begin{array}{r}3.5^{\mathrm{a}} \\
(0.1)\end{array}$ & $\begin{array}{l}109^{b} \\
(3.1)\end{array}$ & $\begin{array}{l}26^{\mathrm{a}} \\
(1.1)\end{array}$ & $\begin{array}{l}235^{\mathrm{a}} \\
(8.2)\end{array}$ & $\begin{array}{r}3.4^{a} \\
(0.1)\end{array}$ \\
\hline
\end{tabular}

${ }^{1}$ Values in parentheses represent S.E.M. See "Materials and Methods" for description of treatments and group sizes.

${ }^{2}$ Treatment means at the same age not sharing a common superscript are statistically different $(P<0.05)$.

Table 3. Changes in nucleic acids and protein in the extensor digitorum longus after nutritional restriction and rehabilitation ${ }^{1,2}$

\begin{tabular}{|c|c|c|c|c|c|c|}
\hline \multirow[b]{2}{*}{ Group } & \multicolumn{2}{|c|}{ Muscle Weight } & \multirow[b]{2}{*}{$\begin{array}{c}\text { Total DNA } \\
(\mu \mathrm{g})\end{array}$} & \multirow[b]{2}{*}{$\begin{array}{l}\text { Total protein } \\
\text { (mg) }\end{array}$} & \multirow[b]{2}{*}{$\frac{\mathrm{mg} \text { Protein }}{\mathrm{mg} \text { DNA }}$} & \multirow[b]{2}{*}{$\frac{\mu \mathrm{g} \text { RNA }}{\mu \mathrm{g} \text { DNA }}$} \\
\hline & mg & $\begin{array}{l}\% \text { Body wt. } \\
\times 10^{-4}\end{array}$ & & & & \\
\hline \multicolumn{7}{|l|}{ Age, 25 days } \\
\hline \multirow[t]{2}{*}{$\mathrm{C}$} & $45^{\mathrm{a}}$ & $4.9^{\mathrm{a}}$ & $44^{a}$ & $6.7^{\mathrm{a}}$ & $151^{\mathrm{a}}$ & $3.9^{\mathrm{a}}$ \\
\hline & (1.4) & $(0.1)$ & (1.9) & $(0.4)$ & $(4.5)$ & $(0.2)$ \\
\hline \multirow[t]{2}{*}{ GR } & $39^{\mathrm{b}}$ & $4.8^{\mathrm{a}}$ & $35^{\mathrm{b}}$ & $5.5^{\mathrm{b}}$ & $148^{\mathrm{a}}$ & $4.2^{a}$ \\
\hline & $(1.5)$ & $(0.1)$ & $(2.1)$ & $(0.2)$ & $(4.9)$ & $(0.2)$ \\
\hline \multirow[t]{2}{*}{ LR } & $25^{c}$ & $5.0^{\mathrm{a}}$ & $24^{c}$ & $2.8^{c}$ & $121^{\mathrm{b}}$ & $4.2^{\mathrm{a}}$ \\
\hline & (1.4) & $(0.2)$ & $(1.0)$ & $(0.2)$ & $(8.0)$ & $(0.3)$ \\
\hline \multicolumn{7}{|c|}{ Age, 100 days } \\
\hline $\mathrm{C}$ & $\begin{array}{l}218^{\mathrm{a}} \\
(8.7)\end{array}$ & $\begin{array}{c}4.5^{\mathrm{a}} \\
(0.2)\end{array}$ & $\begin{array}{l}91^{\mathrm{a}} \\
(5.1)\end{array}$ & $\begin{array}{l}40^{\mathrm{a}} \\
(0.9)\end{array}$ & $\begin{array}{l}427^{\mathrm{a}} \\
(18)\end{array}$ & $\begin{array}{r}3.7^{\mathrm{a}} \\
(0.2)\end{array}$ \\
\hline \multirow[t]{2}{*}{ GR } & $190^{\mathrm{b}}$ & $4.4^{\mathrm{a}}$ & $81^{\text {ab }}$ & $36^{\mathrm{ab}}$ & $451^{a}$ & $3.5^{\mathrm{a}}$ \\
\hline & $(6.9)$ & $(0.1)$ & (5.3) & $(2.0)$ & (22) & $(0.2)$ \\
\hline \multirow[t]{2}{*}{ LR } & $193^{\mathrm{ab}}$ & $4.7^{\mathrm{a}}$ & $73^{\mathrm{b}}$ & $35^{\mathrm{b}}$ & $485^{\mathrm{a}}$ & $4.1^{\mathrm{a}}$ \\
\hline & (10) & $(0.2)$ & (4.1) & $(2.0)$ & $(28)$ & $(0.4)$ \\
\hline \multirow[t]{2}{*}{ PWR } & $205^{\mathrm{ab}}$ & $4.6^{a}$ & $83^{\mathrm{ab}}$ & $37^{\mathrm{ab}}$ & $454^{\mathrm{a}}$ & $4.1^{a}$ \\
\hline & $(6.9)$ & $(0.1)$ & (3.6) & (1.4) & (14) & $(0.2)$ \\
\hline
\end{tabular}

${ }^{1}$ Values in parentheses represent S.E.M. See "Materials and Methods" for description of treatments and group sizes.

${ }^{2}$ Treatment means at the same age not sharing a common superscript are statistically different $(P<0.05)$.

all animals at either 25 or 100 days, these age-related changes amounted to decreases in fiber number of $23 \%$ in the soleus and $18 \%$ in the EDL. Layman et al. (12) reported similar decreases in the number of muscle fibers in the soleus, EDL, plantaris, and biceps brachii from rats during normal growth. In spite of decreased fiber number, total muscle DNA continued to increase over the 165-day period examined. Layman et al. (12) postulated that fusion of fibers was responsible for the decrease in fiber number. In the present study, we have found that chronic $50 \%$ dietary restrictions reduced the number of muscle nuclei by 6 to $20 \%$ but that the number of muscle cells (fibers) was unaffected by the dietary treatments.

Because most studies have indicated that maximum muscle fiber number is attained by birth or shortly thereafter $(15,21,23)$, the finding that the gestational restriction did not cause a permanent reduction in fiber number is of special interest. Although the immediate effect of the gestational restriction on fiber number could not be determined by the Coulter Counter method, our results indicate that a normal number of fibers was present at 25 days of age. Widdowson (29) previously reported that quadriceps muscles from the offspring of guinea pigs restricted during pregnancy contained about half the normal complement of muscle fibers. But Beerman (2) recently reported that a combination gestational and lactational restriction did not change fiber number in the soleus or EDL muscles of rats, and other studies with the rat (16) and the pig (26) have indicated that muscle fiber number was unchanged during nutritionally restricted growth.

At 25 days of age, mean muscle fiber diameters of the soleus from the GR and LR groups were significantly smaller than the $C$ group values. Likewise, the EDL from the LR group had significantly smaller fibers but, surprisingly, fiber diameter in the GR group was not different. At 100 days of age, EDL fiber diameters of the three restricted groups were all statistically less than normal. Soleus fiber diameters for the three restricted groups at 100 days were only slightly smaller. Hegarty and Kim (9) reported that refeeding after a 3-day starvation prompted complete recovery of muscle fiber diameter, but their restriction caused a rapid loss of body weight whereas the animals of the present study 
Table 4. Skeletal muscle fiber number and diameter after gestational, lactational or postweanling dietary restrictions ${ }^{1,2}$

\begin{tabular}{cccccc}
\hline \multirow{2}{*}{ Group } & \multicolumn{2}{c}{ Soleus } & & \multicolumn{2}{c}{ EDL } \\
\cline { 2 - 3 } \cline { 5 - 6 } \cline { 5 - 6 } Age, 25 days & & & & & \\
Diameter & Number & & Diameter ${ }^{3}$ & Number \\
C & $37.1^{\mathrm{a}}$ & $2262^{\mathrm{a}}$ & & $25.3^{\mathrm{a}}$ & $4296^{\mathrm{a}}$ \\
GR & $(0.6)$ & $(62)$ & & $(0.3)$ & $(173)$ \\
& $35.0^{\mathrm{b}}$ & $2472^{\mathrm{a}}$ & & $25.1^{\mathrm{a}}$ & $4216^{\mathrm{a}}$ \\
LR & $(0.6)$ & $(102)$ & & $(0.4)$ & $(162)$ \\
& $27.4^{\mathrm{c}}$ & $2499^{\mathrm{a}}$ & & $20.2^{\mathrm{b}}$ & $4418^{\mathrm{a}}$ \\
Age, 100 days & $(0.7)$ & $(90)$ & & $(0.6)$ & $(154)$ \\
C & & & & \\
& $67.8^{\mathrm{a}}$ & $1910^{\mathrm{a}}$ & & $54.1^{\mathrm{a}}$ & $3439^{\mathrm{a}}$ \\
GR & $(1.8)$ & $(78)$ & & $(0.7)$ & $(114)$ \\
& $66.5^{\mathrm{a}}$ & $1807^{\mathrm{a}}$ & & $48.7^{\mathrm{b}}$ & $3640^{\mathrm{a}}$ \\
LR & $(1.8)$ & $(65)$ & & $(0.8)$ & $(147)$ \\
& $66.2^{\mathrm{a}}$ & $1880^{\mathrm{a}}$ & $51.1^{\mathrm{bc}}$ & $3336^{\mathrm{a}}$ \\
PWR & $(1.5)$ & $(134)$ & $(1.1)$ & $(64)$ \\
& $64.1^{\mathrm{a}}$ & $1828^{\mathrm{a}}$ & $51.4^{\mathrm{c}}$ & $3686^{\mathrm{a}}$ \\
& $(1.3)$ & $(68)$ & $(0.6)$ & $(107)$ \\
\hline
\end{tabular}

'Values in parentheses represent S.E.M. See "Materials and Methods" for description of treatments and group sizes. EDL, extensor digitorium longus.

${ }^{2}$ Treatment means at the same age not sharing a common superscript are statistically different $(P<0.05)$.

${ }^{3}$ Diameter in microns.

grew during the restriction. Studies will have to be continued beyond the end of growth to accurately assess the ability of muscle fiber diameter to recover.

The results of this study suggest that nuclear number (DNA) is the factor controlling postnatal skeletal muscle growth. The ability of muscles to recover from a nutritional restriction appears to directly relate to the ability to achieve a normal complement of muscle nuclei. Muscle fiber number reaches a maximum at birth or shortly thereafter; thus, postnatal muscle growth occurs strictly by hypertrophy of existing fibers. The findings presented here indicated that muscle fiber size rather than fiber number was altered by the restrictions. Because the restrictions had no permanent effect on the ratio of protein/DNA, the apparent stunting of muscle mass appeared to be caused by the reduced number of nuclei.

\section{REFERENCES AND NOTES}

1. Bedi, K. S., Mahon, M., and Smart, J. L.: A quantitative light microscopical study of muscle from adult rats previously undernourished in early life. Proc. Nutr. Soc. (Abstract), 59A (1978).

2. Beerman, D. H.: Skeletal muscle development and growth in offspring of rats nutritionally deprived during gestation and lactation. Fed. Proc., 40: 869 (1981).

3. Ceriotti, G.: A microchemical determination of desoxyribonucleic acid. J. Biol. Chem., 198: 297 (1952).

4. Chow, B. F. and Stephan, J. K.: Fetal undernourishment and growth potential. Nutr. Rep. Int., 4: 245 (1971)

5. Enesco, M. and Leblond, C. P.: Increase in cell number as a factor in the growth of the organs and tissues in the young male rat. J. Embryol. Exp. Morphol., 10: $530(1962)$.
6. Faust, I. M., Johnson, P. R., and Hirsch, J.: Long-term effects of early nutritional experience on the development of obesity in the rat. J. Nutr., 110: 2027 (1980)

7. Gordon, E. E., Kowalski, K., and Fritts, M.: Muscle proteins and DNA in rat quadriceps during growth. Am. J. Physiol., 210: 1033 (1966).

8. Hegarty, P. V. J. and Allen, C. E.: Effect of pre-natal runting on the postnatal development of skeletal muscles in swine and rats. J. Anim. Sci., 46: 1634 (1978).

9. Hegarty, P. V. J. and Kim, K. O.: Changes in skeletal muscle cellularity in starved and refed young rats. Brit. J. Nutr., 44: 123 (1980).

10. Hegarty, P. V. J. and Kim, K. O.: Effects of starvation on tissues from the young of four species, with emphasis on the number and diameter of skeletal muscle fibers. Pediatr. Res., 15: 128 (1981).

11. Huntsberger, D. and Billingsley, P.: Tests of hypotheses. In: Elements of Statistical Inference, pp. 195-218 (Allyn and Bacon, Boston, MA, 1977).

12. Layman, D. K., Hegarty, P. V. J., and Swan, P. B.: Comparison of morphological and biochemical parameters of growth in rat skeletal muscles. J. Anat., 130: 159 (1980).

13. Layman, D, K., Swan, P. B., and Hegarty, P. V. J.: The effect of acute restriction on muscle fiber number in weanling rats. Brit. J. Nutr., 45: 475 (1981).

14. Lowry, O. H., Rosebrough, N. J., Farr, A. L., and Randall, R. J.: Protein measurement with the Folin phenol reagent. J. Biol. Chem., 193: 165 (1951).

15. MacCallum, J. B.: On the histogenesis of the striated muscle fiber, and the growt of the human sartorius muscle. Johns Hopkins Hosp. Bull., 9: 208 (1898).

16. McCarter, R., Yu, B. P., and Radicke, D.: Effects of calorie restriction on contraction of skeletal muscle. Nutr. Rep. Int., 17: 339 (1978).

17. Mirsky, A. E. and Ris, H.: Variable and constant components of chromosomes. Nature 163: 666 (1949).

18. Montgomery, R. D.: Muscle morphology in infantile protein malnutrition. J. Clin. Pathol., 15: 511 (1962).

19. Munro, H. N. and Fleck, A.: The determination of nucleic acids. In: Methods of Biochemical Analysis, D. Glick, ed. Vol 14, pp. 113-176 (Interscience and Wylie, New York, NY, 1966)

20. Munro, H. N. and Gray, J. A. M.: The nucleic acid content of skeletal muscle and liver in mammais of different body size. Comp. Biochem. Physiol. 28: 897 (1969).

21. Rayne, J. and Crawford, G. N. C.: Increase in fiber numbers of the rat pterygoid muscles during postnatal growth. J. Anat. 119: 347 (1975).

22. Reeds, P. J., Jackson, A. A., Picou, D., and Poulter, N.: Muscle mass and composition in malnourished infants and children and changes seen after recovery. Pediatr. Res., 12: 613 (1978).

23. Rowe, R. W. D. and Goldspink, G.: Muscle fiber growth in five different muscles in both sexes of mice. J. Anat., 104: 519 (1969).

24. Rowe, R. W. D.: Effect of low nutrition on size of striated muscle fibers in the mouse. J. Exp. Zool., 167: 353 (1968).

25. Schmidt, G. and Thannhauser, S. J.: A method for the determination of deoxyribonucleic acid, ribonucleic acid, and phospho-proteins in animal tissue. J. Biol. Chem., 161: 83 (1945).

26. Strickland, N. C., Widdowson, E. M., and Goldspink, G.: Effects of severe energy and protein deficiencies on the fibers and nuclei in skeletal muscle of pigs. Brit. J. Nutr., 34: 421 (1975)

27. Thompson, E. H., Levine, A. S., Hegarty, P. V. J., and Allen, C. E.: An automated technique for simultaneous determination of muscle fiber number and diameter. J. Anim. Sci., 48: 329 (1979).

28. Widdowson, E. M and McCance, R. A.: Some effects of accelerating growth. I. General somatic development. Proc. Roy. Soc. Biol. Sci., 152: 188 (1960).

29. Widdowson, E. M.: Harmony of growth. Lancet, 1: 901 (1970).

30. Winick, M. and Noble, A.: Quantitative changes in DNA, RNA, and protein during prenatal and postnatal growth in the rat. Dev. Biol., 12: 451 (1965).

31. Winick, M. and Noble, A.: Cellular response in rats during malnutrition at various ages. J. Nutr., 89: 300 (1966).

32. Vitamin Free Test Casein. Teklad Test Diets. Madison, WI

33. Teklad 10600 vitamin mix. Madison, WI.

34. AIN-76 mineral mix. Teklad. Madison, WI.

35. This research was supported by the National Institute of Health, Institute for Child Health and Human Development (HD 16401) and by the USDA (ILLU 60-336).

36. Requests for reprints should be addressed to: Dr. Donald K. Layman, Department of Foods and Nutrition, Division of Nutritional Sciences, University of Illinois. 905 S. Goodwin, Urbana, IL 61801.

37. Received for publication November 13, 1981 .

38. Accepted for publication October 14, 1982 